\title{
Transmission studies of the newly described apple chlorotic fruit spot viroid using a combined RT-qPCR and droplet digital PCR approach
}

\author{
Thomas Leichtfried $^{1} \cdot$ Helga Reisenzein ${ }^{1} \cdot$ Siegrid Steinkellner ${ }^{2}\left[\right.$ [D $\cdot$ Richard A. Gottsberger $^{1}$
}

Received: 28 February 2020 / Accepted: 15 May 2020 / Published online: 8 July 2020

(c) The Author(s) 2020, corrected publication 2020

\begin{abstract}
The transmission of the apscaviroid tentatively named apple chlorotic fruit spot viroid (ACFSVd) was investigated using a one-step reverse-transcription (RT) droplet digital PCR assay for absolute quantification of the viroid, followed by quantification of relative standard curves by RT-qPCR. Our results indicate that ACFSVd is effectively transmitted by grafting, budding and seeds. No transmission has yet been observed to the viroid-inoculated pome fruit species Pyrus sp. and Cydonia sp. ACFSVd was detected in viruliferous aphids (Myzus persicae, Dysaphis plantaginea) and in codling moths (Cydia pomonella). The viroid was also detected systemically in the infected hemiparasitic plant Viscum album subsp. album (mistletoe).
\end{abstract}

Apple chlorotic fruit spot viroid (ACFSVd) is a putative new pathogenic viroid on apple that was recently detected in the Austrian province of Burgenland. This viroid causes chlorotic fruit spots and bump-like symptoms on the skin of apples, thus reducing fruit quality and making the fruits unmarketable [1]. It is crucial that key epidemiological facts be understood to reduce the risk of the spread of this putative new pathogen. For viroids, several means of dispersal are known, such as horizontal transmission by pruning shears, grafting knives or machinery, or vertical transmission by seeds and pollen [2-5]. Additionally, the international trade of propagative material can play a key role in long-distance transmission, because viroids infect plants systemically $[6,7]$. Vector-based transmission may have a significant influence on the spread of diseases. Important vectors of viroids are green peach aphids (Myzus persicae) and white flies (Trialeurodes vaporariorum) [8-12] as well as bumblebees $[4,13]$. Further unobserved modes of transmission could involve harmful

Handling Editor: Jesús Navas-Castillo.

Electronic supplementary material The online version of this article (https://doi.org/10.1007/s00705-020-04704-5) contains supplementary material, which is available to authorized users.

Siegrid Steinkellner

siegrid.steinkellner@boku.ac.at

1 Institute for Sustainable Plant Protection, Austrian Agency for Health and Food Safety, 1220 Vienna, Austria

2 Institute of Plant Protection, University of Natural Resources and Life Sciences, 3430 Tulln an der Donau, Austria insects (e.g., codling moths) and hemiparasitic plants such as mistletoe (Viscum album subsp. album L.), which is frequently found in extensively managed apple orchards. These plants come directly into contact with host plants through haustoria [14] and can apparently take up genetic material such as RNA [15]. For the detection and characterization of viroids, various techniques can be used, such as biological indexing [16], PCR-based methods [17-19], and nextgeneration sequencing $[1,20,21]$. A qualitative result can be obtained with endpoint RT-PCR, and relative quantification can be achieved by RT-qPCR. For quantification with qPCR, a standard curve with known concentrations of the target is necessary to transform the qPCR output of the quantification cycle $(\mathrm{Cq})$ into absolute concentrations [22, 23]. For culturable microorganisms such as bacteria, cell suspensions with defined concentrations can be prepared from cultures [24]. In contrast, viroids are obligate cell parasites [25], and therefore, it is not possible to define an absolute target concentration of viroid per sample using classical molecular methods. For absolute quantification, digital PCR (dPCR) is a helpful tool for determining the exact number of target copies. One of the main advantages of dPCR is absolute target quantification without reference to a calibration curve [26]. There are different platforms available, which can be distinguished based on their partitions (chambers or droplets) [27]. In this study, droplet digital PCR (ddPCR) was used for the absolute quantification of ACFSVd. This technology has already been used for plant pathogens such as phytoplasma [28], Erwinia amylovora, Ralstonia solanacearum [29], Xylella fastidiosa [30] potato virus Y [22], 
citrus yellow vein clearing virus [31] and citrus tristeza virus [32]. To our knowledge, there is no published report on the use of ddPCR for the quantification of pathogenic viroids in plant tissue. In this study, we investigated the mode of transmission of ACFSVd. We addressed transmission by insects, sap inoculation, infected scions, and seeds. As we found heavy infection in mistletoe on ACFSVd-symptomatic apple trees of cultivar "Ilzer Rose" at the site where this viroid was first described, we also included this possibly new pathway of viroid transmission in this study. For analysis of ACFSVd transmission, we developed a new specific RT-qPCR assay, which was combined with an RT- ddPCR assay for absolute quantification of this viroid.

For RT-qPCR and ddPCR, plant material infected with the ACFSVd isolate (GenBank no. MF521431.2) was collected from symptomatic apple fruit of the local cv. "Ilzer Rose" in the Austrian province of Burgenland. Total RNA was extracted directly from symptomatic apple fruit skins using a Spectrum Plant Total RNA Kit (Sigma Aldrich, St. Louis, USA), following the manufacturer's instructions. The RNA was eluted in $50 \mu \mathrm{l}$ of elution solution, which was provided in the kit and stored at $-20{ }^{\circ} \mathrm{C}$ until use. For absolute quantification by ddPCR, a 1:1,000 dilution was prepared.

Twenty seeds were extracted from ACFSVd-symptomatic apple fruit. For testing the cotyledons, the seed coats of 25 seeds were excised using sterile scalpel blades. Fifty aphids feeding on symptomatic trees and five codling moth larvae feeding on symptomatic apple fruits were collected. The biological materials were frozen at $-80{ }^{\circ} \mathrm{C}$ for $30 \mathrm{~min}$. Seeds, cotyledons and insects were put into a 2-ml Lysing Matrix A tube (MP Biomedical, California, USA) and crushed in a FastPrep-24 instrument (MP Biomedical, California, USA) for $30 \mathrm{~s}$ at $6.5 \mathrm{~m} / \mathrm{s}$. The entire smashed sample was used for total RNA extraction using an RNeasy Plant Mini Kit (QIAGEN, Hilden, Germany), following the manufacturer's instructions. The same commercial kit was used to extract RNA from $100 \mathrm{mg}$ of plant material from twigs, leaves, and 20 buds from symptomatic trees. For the transmission experiments ACFSVd-infected scions were grafted onto two-yearold apple (Malus sylvestris), pear (Pyrus communis), and quince (Cydonia oblonga) trees.

A total of 150 seeds of mistletoe grown on symptomatic apple trees were tested. For this purpose, a phenol:chloroform:isoamyl alcohol extraction as described by Psifidi et al. [33] was used with minor modifications. Mistletoe seeds are surrounded by a viscous substance containing viscin [34]. Due to this sticky substance, a commercial kit could not be used, because viscin causes the liquid to become viscous during the extraction steps, impeding elution, e.g., through silica columns. To separate the seeds from the viscous arillus, the samples were incubated at $30{ }^{\circ} \mathrm{C}$ for $24 \mathrm{~h}$. After the arillus was dried, it could be almost completely removed mechanically from the seeds by scraping it off with sterile scalpel blades. One seed was added to a Lysing Matrix A tube prefilled with $500 \mu \mathrm{l}$ NTES buffer (1 M NaCl, 0.5\% SDS, $10 \mathrm{mM}$, Tris- $\mathrm{HCl}, \mathrm{pH} 8.0,1 \mathrm{mM}$ EDTA) and $500 \mu \mathrm{l}$ of phenol:chloroform:isoamyl alcohol solution (25:24:1) (Applichem, Darmstadt, Germany). The seeds were comminuted using a FastPrep-24 instrument as mentioned above. After a centrifugation step (30 $\mathrm{min}$ at $16,000 \mathrm{~g}, 8^{\circ} \mathrm{C}$ ), the upper aqueous phase was transferred into a new $1.5-\mathrm{ml}$ tube. Then, $500 \mu \mathrm{l}$ of chloroform:isoamyl alcohol (VWR, Pennsylvania, USA) was added to the tube, which was then vortexed and centrifuged at $16,000 \mathrm{~g}$ for $10 \mathrm{~min}$. The aqueous phase was again pipetted into a new $1.5-\mathrm{ml}$ tube, and the nucleic acid was precipitated by adding 1.5 volumes of ice-cold isoamyl alcohol (Merck, Darmstadt, Germany) and 0.1 volumes of sodium acetate $(0.3 \mathrm{M})$ and keeping the sample in a freezer for $12 \mathrm{~h}$. After a centrifugation step $(16,000 \mathrm{~g}, 30 \mathrm{~min})$, the supernatant was discarded. The pellet was washed with $200 \mu \mathrm{l}$ of $70 \%$ ethanol (Scharlab S.L., Barcelona, Spain) and centrifuged for $5 \mathrm{~min}$ at $5200 \mathrm{~g}$. The supernatant was discarded, and this step was repeated. The pellet was vacuum dried using a vacuum concentrator (Eppendorf, Hamburg, Germany) and dissolved in $40 \mu \mathrm{l}$ of PCR-grade water. Seed transmission was tested as described by Kim et al. [35]. For germination, 144 seeds from symptomatic apples were kept in a refrigerator for 60 days to break seed dormancy. The seeds were planted in pots, and seedlings were grown in a glasshouse. After two months, the plantlets were homogenized using a Homex leafpress (Bioreba AG, Reinach, Switzerland) in Bioreba bags, and an aliquot of the homogenate was used for extraction of total RNA using an RNeasy Plant Mini Kit (QIAGEN, Hilden, Germany) following the manufacturer's instructions. Primers ACFSVd-Frt (5'-TTAGGACCGCGGAGCTGTTG-3') and ACFSVd-Rrt (5'-ACGAGTCCCTCGACCCTCT-3') were designed by aligning the full ACFSVd sequence (GenBank no. MF521431.2) obtained from the National Center for Biotechnology (NCBI) using the Primer BLAST tool (Software Primer 3 and BLAST) [36]. The specificity of the newly designed primer for the annealing site was tested in silico at NCBI GenBank and in vitro using 5x HOT FIREPol ${ }^{\circledR}$ EvaGreen ${ }^{\circledR}$ qPCR Supermix (Solis Biodyne, Tartu, Estonia). After in vitro specificity testing with ACFSVd and other related viroids (Supplementary Table S1), a FAM TaqMan minor groove binder (MGB) nonfluorescent quencher hydrolysis probe (ACFSVd-P 5'-FAM-GTTCCT GTGGTGACACCTCC-MBGEQ-3') was synthesized at Eurofins Genomics (Cologne, Germany). The reaction was performed in a 10- $\mu$ l final volume containing, $5 \mu \mathrm{l}$ of $2 \mathrm{x}$ qScript XLT 1-Step RT-qPCR ToughMix (QuantaBio, Beverly, USA), $0.5 \mu \mathrm{l}$ of $10 \mu \mathrm{M}$ forward and reverse primer, $2 \mu \mathrm{l}$ of $1 \mu \mathrm{M}$ probe, $1 \mu \mathrm{l}$ of water and $1 \mu \mathrm{l}$ of template. PCR was performed in a magnetic-induction cycler (Bio Molecular Systems, Australia) under the following conditions: reverse 
transcription at $49{ }^{\circ} \mathrm{C}$ for $30 \mathrm{~min}$, denaturation at $95^{\circ} \mathrm{C}$ for $5 \mathrm{~min}$, and 40 cycles of $95^{\circ} \mathrm{C}$ for $15 \mathrm{~s}$ and $60{ }^{\circ} \mathrm{C}$ for $60 \mathrm{~s}$. The standards for the relative quantification were prepared from the absolutely quantified RNA determined by ddPCR. The standard was serially diluted tenfold down to standard 5 (13.4 copies/ $\mu \mathrm{l})$, and standard 6 was then made by diluting standard $51: 4$, with a resulting copy number of 3.35 . The purpose of the deviating dilution of standard 6 was to obtain a better resolution of the standard curve. For all standards, three technical replicates were used (Fig. 2). ddPCR was carried out on RNA extracted from symptomatic Ilzer Rose apple fruit skin according to the manufacturer's recommendations [37]. The reaction was prepared using a One-Step RT-ddPCR Advanced Kit (Bio-Rad, USA) in a $20-\mu l$ final volume with the following components: $5 \mu \mathrm{l}$ of Supermix, $2 \mu \mathrm{l}$ of reverse transcriptase, $1 \mu \mathrm{l}$ of $300 \mathrm{mM}$ dithiothreitol (DDT), $1.8 \mu \mathrm{l}$ of $10 \mu \mathrm{M}$ forward and reverse primer, $0.5 \mu \mathrm{l}$ of $10 \mu \mathrm{M}$ probe, $6.9 \mu \mathrm{l}$ of water and $1 \mu \mathrm{l}$ of template. The same primers and probe used in the RT-qPCR were used for the RT-ddPCR. The PCR was performed in a VWR PCR Thermal Cycler $\mathrm{XT}^{96}$ Gradient (VWR, USA) at a ramping rate of $2.5^{\circ} \mathrm{C} / \mathrm{s}$. The cycling conditions were adapted to the manufacturer's protocol [37]. For the optimization of the RT-ddPCR reaction, different annealing temperatures $\left(60-55^{\circ} \mathrm{C}\right)$ and primer and probe concentrations were used (data not shown). For absolute quantification, the QX200 droplet reader was used with QuantaSoft software version 1.7.4.0971 (Bio-Rad, USA) for droplet counting. More than 10,000 accepted droplets were required for each well for them to be used for further processing [23].

After testing of viroids of different species for specificity (Supplementary Table S1) and in silico comparison of primers and probes with sequences from the NCBI GenBank database, the assay proved to be $100 \%$ specific for ACFSVd. The expected fragment size was calculated to be $128 \mathrm{bp}$, and this was confirmed using a QIAxcel capillary electrophoresis system (QIAGEN, Hilden, Germany) and a screening cartridge with standard settings (data not shown). The analytical sensitivity of the assay was determined by preparing a standard curve using three replicates of a dilution series. For the correlation with absolute copy numbers, the same sample used in the ddPCR was used for the dilution series (Fig. 2) and was detected in three replicates down to a calculated concentration of 3 viroid molecules per $\mu$. The dilution with 3 viroid RNA molecules was always amplified by the assay, with cycle threshold $\left(\mathrm{C}_{\mathrm{t}}\right)$ values of approximately 36 (Fig. 2). The efficiency of the assay could be shown by analysing the standard curve [24]. The equation was $y=-3.05 x$ +36.23 , and the calculated efficiency was $1.13(113 \%)$. The correlation coefficient of the standard curves ( $r$-squared) was 0.98 . The tested samples were all set in relation to the standard curve.
Different primers, probe concentrations, and annealing temperatures were tested to optimize the resolution of positive and negative clustered droplets. The best droplet resolution was achieved by using a 1:1,000 dilution of the RNA extracted from symptomatic apple fruit skin, $900 \mathrm{nM}$ primers, $250 \mathrm{nM}$ probe, and an annealing temperature of $56{ }^{\circ} \mathrm{C}$. The threshold for droplet positivity was set manually at horizontal line 2,674 and Ch1 amplitude (Fig. 1). The mean concentration of detected ACFSVd target copies (three technical replicates) in the material tested from 100 mg of symptomatic apple fruit skins was 1,336,000 copies/ $\mu \mathrm{l}$ (calculated value) $\pm 54,809$ (SD). The average number of targets per droplet ( $\lambda$-value) was calculated using the following equation: $\lambda=-\ln \times(1-k / n)$ [38]. From three technical replicates, the range of accepted droplets was 12,683 to 15,747 . The range of positive droplets was 690 to 842 , and the range of the $\lambda$-value was 0.05495 to 0.05942 .

ACFSVd could successfully be transmitted to healthy apple trees by top grafting and budding [1]. Transmission to Pyrus sp. or Cydonia sp. could not yet be confirmed by RT-qPCR.

ACFSVd was detected in apple seeds and in dissected embryos (Table 1). Seedlings that germinated from infected apple seeds showed an infection rate of $2.8 \%$. Furthermore, the viroid was detected in aphids (M. persicae, D. plantaginea) and in larvae of $C$. pomonella that had been feeding directly on symptomatic apples. ACFSVd was identified in the leaves, stems and seeds (without the arillus) of $V$. album subsp. album. The amount of ACFSVd copies/sample detected in C. pomonella larvae extracted from symptomatic fruits ranged from $1.48 \times 10^{5}$ to $1.54 \times 10^{5}$. Germinated seedlings showed an infection rate of $2.8 \%$. The viroid titer of 30 to 400 copies/seed was low. ACFSVd could also be detected in aphids with a viroid titer of 100 to 800 copies/ insect. Increased amounts of viroid were found in the plant materials and buds of symptomatic trees. (Table 1).

In this study, RT-qPCR and RT-ddPCR were used to detect ACFSVd in a transmission study based on absolute quantification of the viroid. ACFSVd consists of a small RNA molecule of $354 \mathrm{nt}$ [1]. An RT-qPCR assay was developed to detect and quantify ACFSVd in infected plant tissues and viruliferous insects. For relative quantification, standard curves were used for qPCR [39]. Here, we combined ddPCR and standard curves generated by RT-qPCR for relative quantification of the viroid based on absolute quantities (target copies). The main advantage of this new application of ddPCR and RT-qPCR is that the absolute quantification has to be done only for the positive control and then can be used for defined standard curves in qPCR. These defined standard curves can be applied to determine the detection sensitivity of qPCR assays, set detection limits used in quality management, and determine transmission rates. Furthermore, this 


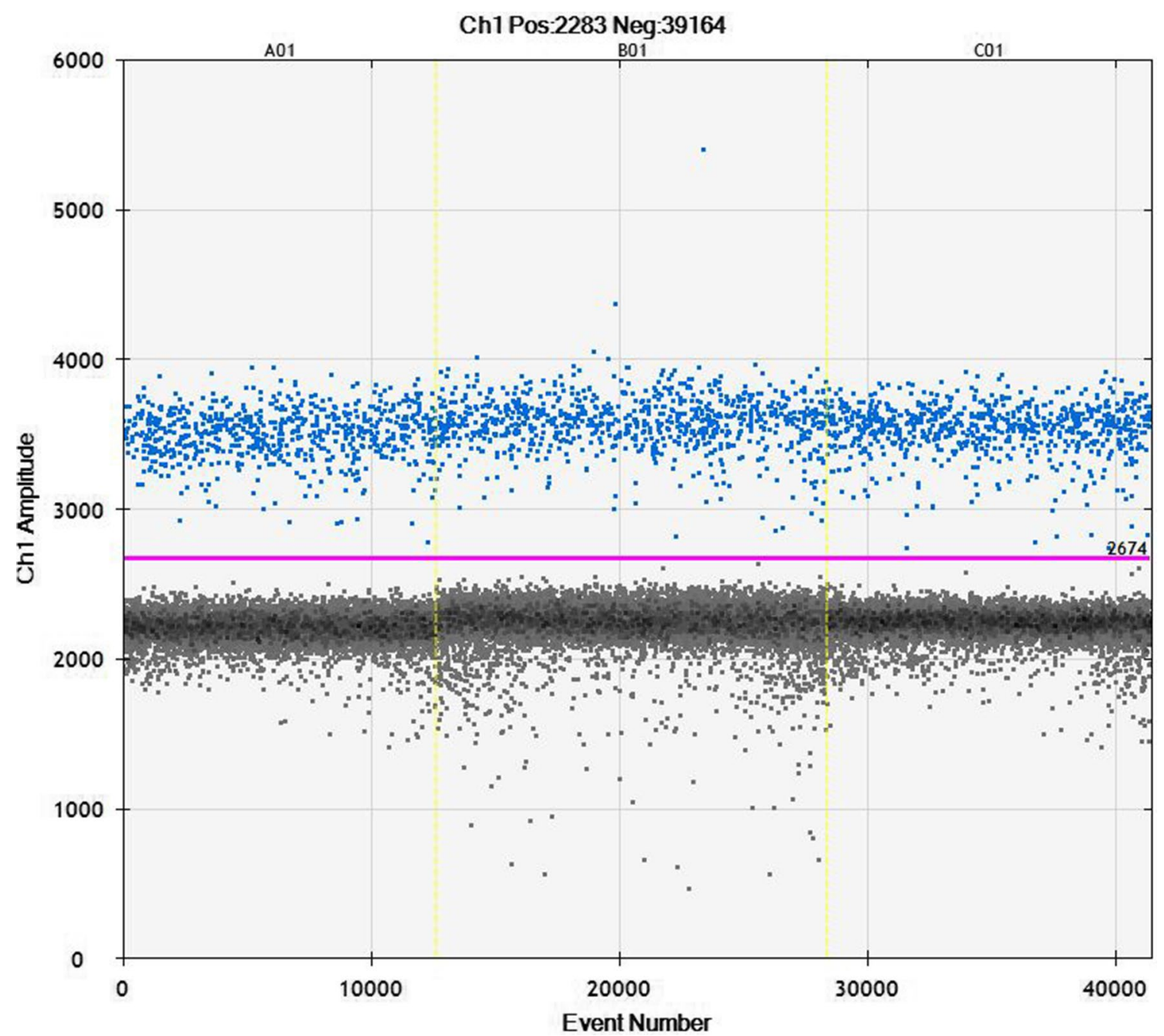

Fig. 1 1D amplitude view of a ddPCR ACFSVd run. The best cluster of positive (upper cluster) and negative (lower cluster) droplets was observed when using $900 \mathrm{nM}$ primers and $250 \mathrm{nM}$ probe

Fig. 2 Standard curve and fluorescence amplification plot of six standards (dilutions) and three technical replicates. The ACFSVd standard curves from 1,336 copies $\times 10^{5} / \mu 1$ to 3.35 copies/ $\mu$ in three replicates (left to right) were drawn using MIC software (v 2.6.4)

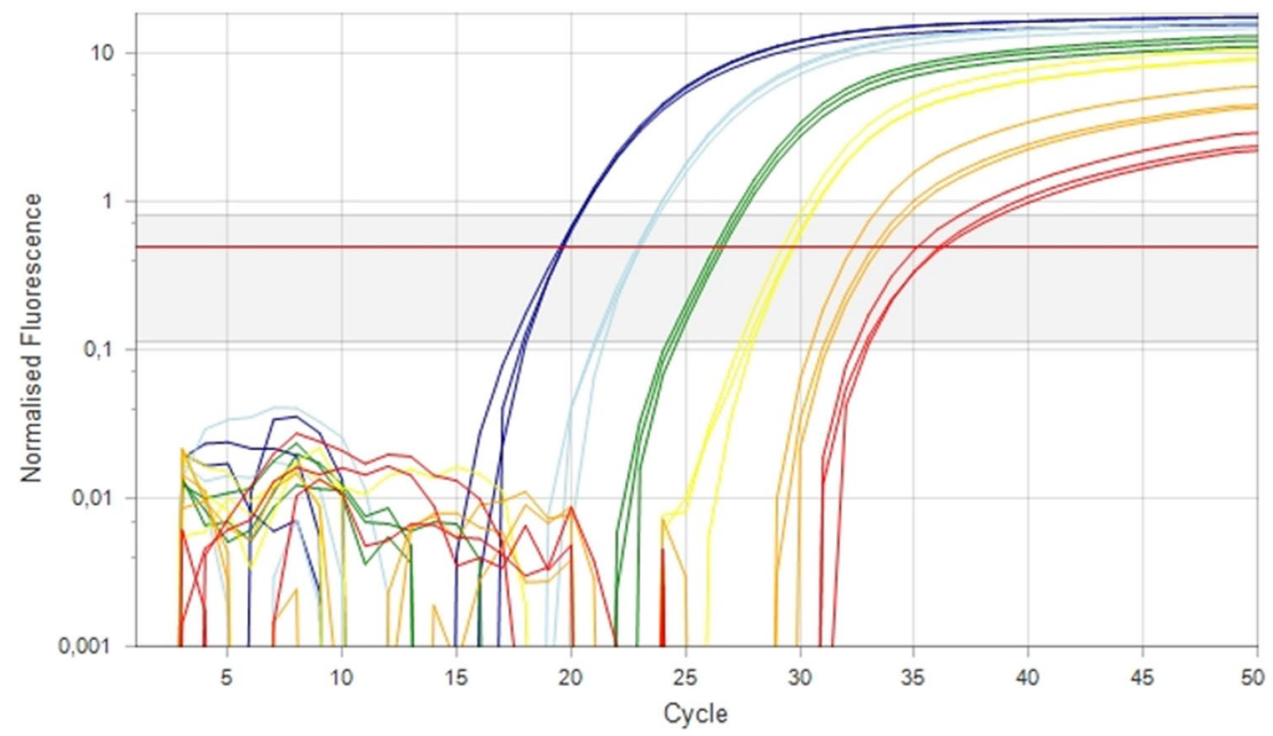


Table 1 Results obtained with different samples and determination of target copies/sample quantified by RT-qPCR

\begin{tabular}{|c|c|c|}
\hline Sample material & $\begin{array}{l}\text { ACFSVd } \\
\text { RNA copies/sample } \\
\text { (minimum) }\end{array}$ & $\begin{array}{l}\text { ACFSVd } \\
\text { RNA copies/sample } \\
\text { (maximum) }\end{array}$ \\
\hline Seeds from symptomatic apple fruit & 6,000 & 220,000 \\
\hline Cotyledon from symptomatic apple fruit & 2,000 & 500,000 \\
\hline Seedling from symptomatic apple fruit & 30 & 400 \\
\hline Seeds (V. album subsp. album) & 50 & 1,900 \\
\hline Plant material (100 mg of V. album subsp. album) & 200 & 1.200 \\
\hline Plant material (100 mg of phloem and leaves) from symptomatic apple trees & $1.5 \times 10^{8}$ & $1.2 \times 10^{9}$ \\
\hline One bud from a symptomatic apple tree & 3.000 & $7.7 \times 10^{6}$ \\
\hline Aphids (M. persicae, D. plantaginea) from a symptomatic apple tree & 100 & 800 \\
\hline Larvae of $C$. pomonella from symptomatic apple fruit & 148,000 & 154,000 \\
\hline
\end{tabular}

method is more cost-effective and time-saving than determining the absolute target copies for each sample.

In our study, the viroid titer in buds and twigs from symptomatic apples was high. Our results support the assumption that ACFSVd could be transmitted very efficiently by horizontal transmission, such as via top-grafting, budding, and propagative material. Vertical transmission was confirmed by testing germinated seedlings. The infection rate of $2.8 \%$ was slightly lower than that of apple scar skin viroid (ASSVd) (7.7\%) [35]. The low infection (or seed transmission rate) could be explained by the generally low viroid titer of 30 to 400 copies/seed. To our knowledge, vertical transmission has only been reported for the previously mentioned viroids in the genus Apscaviroid. In our study, ACF$\mathrm{SVd}$ was also detected in dissected cotyledons of infected apple seeds. The number of ACFSVd molecules was similar in seeds and cotyledons, indicating that ACFSVd is mostly located in the embryo rather than in the seed coat. Horizontal transmission was confirmed by transmission via budding from infected plants to apple trees of the cvs. Topaz and Gala and the rootstock M9. However, no symptoms on apple fruit could be recorded because the trees were not yet in a generative phase. Transmission by grafting to other pome fruits such as, $P$. communis and $C$. oblonga could not be confirmed. Our tests will be ongoing for the next few years to clarify the susceptibility of members of taxa other than Malus sp. to ACFSVd. To date, no apscaviroid transmission to pome fruits by insects has been reported [40-42], while one instance of transmission to plants other than pome fruits has been reported. Walia et al. [8] reported the transmission of ASSVd from infected cucumber and bean plants to several herbaceous plant species by Trialeurodes vaporariorum. We found that the titer of ACFSVd in feeding insects is generally low. However, this may be the reason why apscaviroids are not readily transmitted by feeding insects. Nielsen et al. [43] demonstrated that insects with a low titer of potato spindle tuber viroid were not able to transmit the viroid under experimental conditions, concluding that a larger number of target copies is required for viroids to be effectively transmitted to other plants or hosts. In our study, the ACFSVd titer in $C$. pomonella larvae was significantly higher than that in aphids. Further research must be carried out to clarify whether this insect might be a new potential vector of viroids to pome fruits. Another possible new pathway of ACFSVd transmission is by mistletoes. These hemiparasitic plants are in contact with their hosts, such as apples and other Rosaceae species [44], by haustoria [14]. In this way, mistletoes absorb water and nutrients [45-47]. For another parasitic plant, Cuscuta spp., it is known that haustoria also transfer macromolecules [48], mRNAs [49], metabolites [50], and pathogens such as viroids [51], viruses [52] and phytoplasmas [53]. Thus, an exchange of ACFSVd RNA molecules between mistletoes and their host plants has to be considered. Moreover, some bird species feeding on seeds of mistletoe are able to distribute the seeds over a long distance [54, 55], and ACFSVd-infected mistletoe seeds could also be spread in this way. For the seed testing of $V$. album subsp. album, an RNA extraction procedure was adapted, optimized, and used successfully for these viscin-containing samples. However, in our study, we detected ACFSVd not only in seeds but also in all other parts of the mistletoe. In particular, the spread of infected mistletoe seeds could be a so far undiscovered pathway for the distribution of plantpathogenic viroids in tree hosts. In summary, we show that ACFSVd is transmitted by top grafting and budding. The viroid is seed-borne, seed-transmitted, and detected in viruliferous aphids and codling moths as well as infected mistletoe seeds.

Acknowledgements Open access funding was provided by the University of Natural Resources and Life Sciences Vienna (BOKU). The authors gratefully thank Rupert Hochegger and Walter Mayer (Austrian Agency for Health and Food Safety, Institute for Food Safety, Vienna), who provided access to the ddPCR equipment. 


\section{Compliance with ethical standards}

Conflict of interest The authors declare that they have no conflicts of interest.

Ethical approval Our research complies with established ethical standards. The authors declare no competing financial interests. This research did not contain studies involving human participants or vertebrates by any of the authors.

Open Access This article is licensed under a Creative Commons Attribution 4.0 International License, which permits use, sharing, adaptation, distribution and reproduction in any medium or format, as long as you give appropriate credit to the original author(s) and the source, provide a link to the Creative Commons licence, and indicate if changes were made. The images or other third party material in this article are included in the article's Creative Commons licence, unless indicated otherwise in a credit line to the material. If material is not included in the article's Creative Commons licence and your intended use is not permitted by statutory regulation or exceeds the permitted use, you will need to obtain permission directly from the copyright holder. To view a copy of this licence, visit http://creativecommons.org/licenses/by/4.0/.

\section{References}

1. Leichtfried T, Dobrovolny S, Reisenzein H et al (2019) Apple chlorotic fruit spot viroid: a putative new pathogenic viroid on apple characterized by next-generation sequencing. Arch Virol 164:3137-3140. https://doi.org/10.1007/s00705-019-04420-9

2. Škorić D (2017) Viroid Biology. In: Hadidi A, Flores R, Randles JW, Palukaitis P (eds) Viroids and satellites. Elsevier/Academic Press, London, pp 53-61

3. Verhoeven J, Jansen CCC, Roenhorst JW et al (2009) Pepper chat fruit viroid: Biological and molecular properties of a proposed new species of the genus Pospiviroid. Virus Res 144:209-214. https://doi.org/10.1016/j.virusres.2009.05.002

4. Antignus Y, Lachman O, Pearlsman M (2007) Spread of tomato apical stunt viroid (TASVd) in greenhouse tomato crops is associated with seed transmission and bumble bee activity. Plant Dis 91:47-50. https://doi.org/10.1094/PD-91-0047

5. Pacumbaba EP, Zelazny B, Orense JC, Rillo EP (1994) Evidence for pollen and seed transmission of the coconut cadang-cadang viroid in Cocos nucifera. J Phytopathol 142:37-42. https://doi. org/10.1111/j.1439-0434.1994.tb00005.x

6. Di Serio F, Martínez de Alba A-E, Navarro B et al (2010) RNAdependent RNA polymerase 6 delays accumulation and precludes meristem invasion of a viroid that replicates in the nucleus. J Virol 84:2477. https://doi.org/10.1128/JVI.02336-09

7. Singh RP, Dilworth AD (2003) Biology. In: Hadidi A, Flores R, Randles JW, Semancik JS (eds) Viroids. CSIRO, Collingwood, pp 30-48

8. Walia Y, Dhir S, Zaidi AA, Hallan V (2015) Apple scar skin viroid naked RNA is actively transmitted by the whitefly Trialeurodes vaporariorum. RNA Biol 12:1131-1138. https://doi. org/10.1080/15476286.2015.1086863

9. Syller J, Marczewski W, Pawłowicz J (1997) Transmission by aphids of potato spindle tuber viroid encapsidated by potato leafroll luteovirus particles. Eur J Plant Pathol 103:285-289. https:// doi.org/10.1023/A:1008648822190
10. Querci M, Owens RA, Bartolini I et al (1997) Evidence for heterologous encapsidation of potato spindle tuber viroid in particles of potato leafroll virus. J Gen Virol 78:1207-1211

11. Salazar LF, Querci M, Bartolini I, Lazarte V (1995) Aphid transmission of potato spindle tuber viroid assisted by potato leaf roll virus. Fitopatologia 56-58

12. Galindo J, López M, Aguilar T (1986) Significance of Myzus persicae in the spread of tomato planta macho viroid. Fitopatol Bras 400-410

13. Matsuura S, Matsushita Y, Kozuka R et al (2009) Transmission of Tomato chlorotic dwarf viroid by bumblebees (Bombus ignitus) in tomato plants. Eur J Plant Pathol 126:111. https://doi.org/10.1007/ s10658-009-9515-2

14. Salle G (1983) Germination and establishment of Viscum album L. In: Calder M, Bernhardt P (eds) The biology of mistletoes. Academic Press, Sydney, pp 145-159

15. Yoshida S, Cui S, Ichihashi Y, Shirasu K (2016) The haustorium, a specialized invasive organ in parasitic plants. Annu Rev Plant Biol 67:643-667. https://doi.org/10.1146/annurev-arplant-04301 5-111702

16. Hadidi A, Barba M, Hong V, Hallan V (2017) Apple scar skin viroid. In: Hadidi A, Flores R, Randles JW, Palukaitis P (eds) Viroids and satellites. Elsevier/Academic Press, London, pp 217-228

17. Luigi M, Faggioli F (2011) Development of quantitative realtime RT-PCR for the detection and quantification of Peach latent mosaic viroid. Eur J Plant Pathol 130:109-116. https://doi. org/10.1007/s10658-010-9738-2

18. Boonham N, Pérez LG, Mendez MS et al (2004) Development of a real-time RT-PCR assay for the detection of Potato spindle tuber viroid. J Virol Methods 116:139-146. https://doi.org/10.1016/j. jviromet.2003.11.005

19. Sano T, Yoshida H, Goshono M et al (2004) Characterization of a new viroid strain from hops: evidence for viroid speciation by isolation in different host species. J Gen Plant Pathol 70:181-187. https://doi.org/10.1007/s10327-004-0105-z

20. Barba M, Hadidi A (2017) Application of next-generation sequencing technologies to viroids. In: Hadidi A, Flores R, Randles JW, Palukaitis P (eds) Viroids and satellites. Elsevier/Academic Press, London, pp 401-412

21. Al Rwahnih M, Daubert S, Golino D, Rowhani A (2009) Deep sequencing analysis of RNAs from a grapevine showing Syrah decline symptoms reveals a multiple virus infection that includes a novel virus. Virology 387:395-401. https://doi.org/10.1016/j. virol.2009.02.028

22. Mehle N, Dobnik D, Ravnikar M, Pompe Novak M (2018) Validated reverse transcription droplet digital PCR serves as a higher order method for absolute quantification of Potato virus Y strains. Anal Bioanal Chem 410:3815-3825. https://doi.org/10.1007/ s00216-018-1053-3

23. Gutiérrez-Aguirre I, Rački N, Dreo T, Ravnikar M (2015) Droplet digital PCR for absolute quantification of pathogens. In: Lacomme $\mathrm{C}$ (ed) Plant pathology: techniques and protocols. Springer, New York, pp 331-347

24. Gottsberger RA (2010) Development and evaluation of a real-time PCR assay targeting chromosomal DNA of Erwinia amylovora. Lett Appl Microbiol 51:285-292. https://doi.org/10.1111/j.1472765X.2010.02892.x

25. Owens RA (2008) Viroids. In: Roossinck MJ (ed) Plant virus evolution. Springer, Berlin, pp 83-108

26. Pecaro S, Berben G, Burns M et al (2019) Overview and recommendations for the application of digital PCR, EUR $29673 \mathrm{EN}$. Publ Off Eur Union Luxemb. https://doi.org/10.2760/192883

27. Baker M (2012) Digital PCR hits its stride. Nat Methods 9:541544. https://doi.org/10.1038/nmeth.2027 
28. Mehle N, Dreo T (2019) Quantitative analysis with droplet digital PCR. In: Musetti R, Pagliari L (eds) Phytoplasmas: methods and protocols. Springer, New York, pp 171-186

29. Dreo T, Pirc M, Ramšak Ž et al (2014) Optimising droplet digital PCR analysis approaches for detection and quantification of bacteria: a case study of fire blight and potato brown rot. Anal Bioanal Chem 406:6513-6528. https://doi.org/10.1007/s0021 6-014-8084-1

30. Dupas E, Legendre B, Olivier V et al (2019) Comparison of realtime PCR and droplet digital PCR for the detection of Xylella fastidiosa in plants. J Microbiol Methods 162:86-95. https://doi. org/10.1016/j.mimet.2019.05.010

31. Liu Y, Wang Y, Wang Q et al (2019) Development of a sensitive and reliable reverse transcription droplet digital PCR assay for the detection of citrus yellow vein clearing virus. Arch Virol 164:691-697. https://doi.org/10.1007/s00705-018-04123-7

32. Selvaraj V, Maheshwari Y, Hajeri S, Yokomi R (2019) A rapid detection tool for VT isolates of Citrus tristeza virus by immunocapture-reverse transcriptase loop-mediated isothermal amplification assay. PLOS ONE 14:e0222170. https://doi.org/10.1371/ journal.pone. 0222170

33. Psifidi A, Dovas CI, Banos G (2010) A comparison of six methods for genomic DNA extraction suitable for PCR-based genotyping applications using ovine milk samples. Mol Cell Probes 24:93-98. https://doi.org/10.1016/j.mcp.2009.11.001

34. Szmidla H, Tkaczyk M, Plewa R, et al (2019) Impact of common Mistletoe (Viscum album L.) on Scots pine forests-a call for action. Forests. https://doi.org/10.3390/f10100847

35. Kim H-R, Lee S-H, Lee D-H et al (2006) Transmission of Apple scar skin viroid by grafting, using contaminated pruning equipment, and planting infected seeds. Plant Pathol J 22:63-67. https ://doi.org/10.5423/PPJ.2006.22.1.063

36. Ye J, Coulouris G, Zaretskaya I et al (2012) PrimerBLAST: A tool to design target-specific primers for polymerase chain reaction. BMC Bioinform 13:134. https://doi. org/10.1186/1471-2105-13-134

37. Bio-Rad Droplet, DigitalTM PCR applications guide-Bio-Rad. http://www.bio-rad.com/webroot/web/pdf/lsr/literature/Bulle tin_6407.pdf. Accessed 10 Oct 2019

38. Huggett JF, Foy CA, Benes V et al (2013) The Digital MIQE guidelines: minimum information for publication of quantitative digital PCR experiments. Clin Chem 59:892-902. https://doi. org/10.1373/clinchem.2013.206375

39. Pfaffl MW (2001) A new mathematical model for relative quantification in real-time RT-PCR. Nucleic Acids Res 29:e45. https:// doi.org/10.1093/nar/29.9.e45

40. Hadidi A, Barba MM (2011) Apple scar skin viroid. In: Hadidi A, Barba M, Candresse T, Jelkmann W (eds) Virus and virus-like diseases of pome and stone fruits. The American Phytopathological Society, Minnesota, pp 57-62

41. Flores R, Ambrós LG, Hernández C (2011) Pear blister canker viroid. In: Hadidi A, Barba M, Candresse T, Jelkmann W (eds) Virus and virus-like diseases of pome and stone fruits. The American Phytopathological Society, Minnesota, pp 63-66

42. Di Serio F, Malfitano M, Alioto D et al (2011) Apple dimple fruit viroid. In: Hadidi A, Barba M, Candresse T, Jelkmann W (eds) Virus and virus-like diseases of pome and stone fruits. The American Phytopathological Society, Minnesota, pp 49-52
43. Nielsen SL, Enkegaard A, Nicolaisen M et al (2012) No transmission of Potato spindle tuber viroid shown in experiments with thrips (Frankliniella occidentalis, Thrips tabaci), honey bees (Apis mellifera) and bumblebees (Bombus terrestris). Eur J Plant Pathol 133:505-509. https://doi.org/10.1007/s10658-012-9937-0

44. Barney CW, Hawksworth FG, Geils BW (1998) Hosts of Viscum album. Eur J For Pathol 28:187-208. https://doi. org/10.1111/j.1439-0329.1998.tb01249.x

45. Glatzel G, Geils BW (2008) Mistletoe ecophysiology: host-parasite interactionsThis review is one of a collection of papers based on a presentation from the Stem and Shoot Fungal Pathogens and Parasitic Plants: the Values of Biological Diversity session of the XXII International Union of Forestry Research Organization World Congress meeting held in Brisbane, Queensland, Australia, in 2005. Botany 87:10-15. https://doi.org/10.1139/B08-096

46. Popp M, Richter A (1998) Ecophysiology of xylem-tapping mistletoes. In: Behnke H-D, Esser K, Kadereit JW et al (eds) Progress in botany: genetics cell biology and physiology ecology and vegetation science. Springer, Berlin, pp 659-674

47. Schulze E-D, Turner NC, Glatzel G (1984) Carbon, water and nutrient relations of two mistletoes and their hosts: a hypothesis*. Plant cell environ 7:293-299. https://doi.org/10.1111/1365-3040. ep11589756

48. Haupt S, Oparka KJ, Sauer N, Neumann S (2001) Macromolecular trafficking between Nicotiana tabacum and the holoparasite Cuscuta reflexa. J Exp Bot 52:173-177. https://doi.org/10.1093/ jexbot/52.354.173

49. Kim G, Westwood JH (2015) Macromolecule exchange in Cuscuta-host plant interactions. Curr Opin Plant Biol 26:20-25. https ://doi.org/10.1016/j.pbi.2015.05.012

50. Hibberd JM, Dieter Jeschke W (2001) Solute flux into parasitic plants. J Exp Bot 52:2043-2049. https://doi.org/10.1093/jexbo $\mathrm{t} / 52.363 .2043$

51. van Dorst HJM, Peters D (1974) Some biological observations on pale fruit, a viroid-incited disease of cucumber. Neth J Plant Pathol 80:85-96. https://doi.org/10.1007/BF01980613

52. Birschwilks M, Haupt S, Hofius D, Neumann S (2006) Transfer of phloem-mobile substances from the host plants to the holoparasite Cuscuta sp. J Exp Bot 57:911-921. https://doi.org/10.1093/jxb/ erj076

53. Pribylova J, Spak J (2013) Dodder transmission of phytoplasmas. Methods Mol Biol Clifton NJ 938:41-46. https://doi. org/10.1007/978-1-62703-089-2_4

54. Briggs J (2011) Mistletoe (Viscum album): A brief review of its local status with recent observations on its insects associations and conservation problems. Proc Cotteswold Nat Field Club XLV II: $181-191$

55. Zuber D (2004) Biological flora of Central Europe: Viscum album L. Flora Morphol Distrib Funct Ecol Plants 199:181-203. https:// doi.org/10.1078/0367-2530-00147

Publisher's Note Springer Nature remains neutral with regard to jurisdictional claims in published maps and institutional affiliations. 